\title{
Penapisan Fitokimia, Kadar Kurkuminoid dan Aktivitas Antibakteri Temu Hitam (Curcuma aeruginosa (Christm) Roscoe.), Temu Putih (Curcuma zedoaria Roxb.) dan Temulawak (Curcuma xanthorrhiza Roxb.)
}

\author{
Lia Marliani ${ }^{1}$, Ika Kurnia Sukmawati ${ }^{1}$, Dadang Juanda ${ }^{1}$, Elmadhita Anjani ${ }^{1}$, Ira Anggraeni ${ }^{1}$ \\ ${ }^{1}$ Fakultas Farmasi, Universitas Bhakti Kencana, Bandung \\ Email: lia.marliani@bku.ac.id
}

\begin{abstract}
The content of secondary metabolites in the rhizome of the Curcuma genus such as Black turmeric (Curcuma aeruginosa Roxb.), White turmeric (Curcuma zedoaria (Christm.) Roscoe) and Java turmeric (Curcuma xanthorrhiza Roxb.) play a role in various pharmacological activities. One of them is the content of the curcuminoid compounds which have been proved to have antibacterial activity. This study aims to screen the content of secondary metabolite compounds, determine curcuminoid content and verify the antibacterial activity of the extracts of Black turmeric (Curcuma aeruginosa Roxb.), White turmeric (Curcuma zedoaria (Christm.) Roscoe) and Java turmeric (Curcuma xanthorrhiza Roxb.). Extraction was carried out by the maceration method using 95\% ethanol as solvent. Phytochemical screening was tested for the content of alkaloid, polyphenols, flavonoids, quinones, tannins, saponins, and steroids/ triterpenoids compounds. Determination of curcuminoid content by UV-Vis Spectrophotometry method. The antibacterial activity test was carried out by the microdilution method against Staphylococcus aureus, Staphylococcus epidermidis, and Propionibacterium acne bacteria. The results of phytochemical screening showed that the three extracts contained polyphenols and flavonoids. Quinone compounds are only contained in the extract of Black turmeric and Java turmeric. Saponin compounds were only detected in Black turmeric and White turmeric extracts. Meanwhile, steroid/ triterpenoid compounds were detected in the extract of White turmeric and Java turmeric. The results of curcuminoid content determination on the three extracts showed that the Java turmeric extract had the highest content of curcuminoids $(16.07 \pm 0.023 \mathrm{mg} \mathrm{CE} / \mathrm{g}$ extract). The results of the antibacterial test showed the strongest activity of the three test samples shown by Java turmeric extract with a minimum inhibitory concentration (MIC) value of $64 \mu \mathrm{g} / \mathrm{mL}$ against Staphylococcus aureus bacteria; $256 \mu \mathrm{g} / \mathrm{mL}$ against Staphylococcus epidermidis bacteria; and $32 \mu \mathrm{g} / \mathrm{mL}$ against the Propionibacterium acne bacteria. These results indicate that Java turmeric extract is more active against Propionibacterium acne bacteria.
\end{abstract}

Key word: Curcuma, Zingiberaceae, Curcuminoid, Antibacterial

\section{Abstrak}

Kandungan metabolit sekunder pada Rimpang tanaman Genus Curcuma seperti Temu hitam (Curcuma aeruginosa Roxb.), Temu putih (Curcuma zedoaria (Christm.) Roscoe) dan Temulawak (Curcuma xanthorrhiza Roxb.) berperan dalam berbagai aktivitas farmakologi. Salah satunya adalah kandungan senyawa golongan kurkuminoid yang teruji memiliki aktivitas antibakteri. Penelitian ini bertujuan untuk menapis kandungan golongan senyawa metabolit sekunder, menetapkan kadar kurkuminoid serta menguji aktivitas antibakteri ekstrak rimpang Temu hitam (Curcuma aeruginosa Roxb.), Temu putih (Curcuma zedoaria (Christm.) Roscoe) dan Temulawak (Curcuma xanthorrhiza Roxb.). Ekstraksi dilakukan menggunakan metode maserasi dengan pelarut etanol 95\%. Penapisan fitokimia diujikan terhadap kandungan senyawa alkaloid, polifenol, flavonoid, kuinon, tannin, saponin, dan steroid/triterpenoid. Penetapan kadar kandungan kurkuminoid menggunakan Spektrofotometri UV-Vis. Pengujian aktivitas antibakteri dilakukan dengan metode mikrodilusi terhadap bakteri Staphylococcus aureus, Staphylococcus epidermidis, dan Propionibacterium acne. Hasil penapisan fitokimia menunjukkan ketiga ekstrak mengandung senyawa polifenol dan flavonoid. Senyawa kuinon hanya terkandung pada ekstrak temu hitam dan temu lawak. Senyawa saponin hanya terdeteksi pada ekstrak temu hitam dan temu putih. Sedangkan senyawa steroid/triterpenoid terdeteksi pada ekstrak temu putih dan temulawak. Hasil penetapan kadar kurkuminoid pada ketiga ekstrak menunjukkan ekstrak temulawak memiliki kandungan kurkuminoid yang paling tinggi (16.07 $\pm 0.023 \mathrm{mg} \mathrm{CE} / \mathrm{g}$ ekstrak). Hasil pengujian antibakteri menunjukkan aktivitas paling kuat dari ketiga sampel uji ditunjukkan ekstrak temulawak dengan nilai konsentrasi hambat minimum (KHM) $64 \mu \mathrm{g} / \mathrm{mL}$ terhadap bakteri Staphylococcus aureus; $256 \mu \mathrm{g} / \mathrm{mL}$ terhadap bakteri Staphylococcus epidermidis; dan $32 \mu \mathrm{g} / \mathrm{mL}$ terhadap bakteri Propionibacterium acne. Hasil ini menunjukkan bahwa ekstrak temulawak lebih aktif terhadap bakteri Propionibacterium acne.

Kata Kunci: Curcuma, Zingiberaceae, Kurkuminoid, Antibakteri 


\section{PENDAHULUAN}

Tanaman genus Curcuma merupakan tanaman obat keluarga (TOGA) yang dikenal oleh masyarakat Indonesia. Temu hitam (Curcuma aeruginosa Roxb.), Temu putih (Curcuma zedoaria (Christm.) Roscoe) dan Temulawak (Curcuma xanthorrhiza Roxb.) merupakan spesies yang familiar dan digunakan sebagai bahan obat tradisional $^{[1]}$.

Tiga spesies dari genus Curcuma tersebut memiliki beberapa kandungan metabolit sekunder yang berperan dalam aktivitas farmakologinya. Temu hitam (Curcuma aeruginosa Roxb.) mengandung minyak atsiri, kurkumin, tanin, kurkumol, kurkumenol, isokurkumenol, kurzerenon, kurdion, kurkumalakton, germakron, $\quad \beta, \quad \alpha, \quad \gamma$-elemene, linderazulene, demethyoxykurkumin, bisdemethoxykurkumin ${ }^{[2-4]}$. Rimpang temu hitam sudah digunakan sebagai tanaman obat secara empiris, diantaranya digunakan sebagai antidiare, antimikroba, asma, tumor, dan bronkhitis ${ }^{[5,6]}$. Kandungan flavonoid pada temu hitam berkhasiat sebagai antihipertensi, merangsang pembentukan estrogen, antifungal, dan insektisida ${ }^{[7]}$.

Senyawa metabolit sekunder utama yang terkandung pada temu putih berupa minyak menguap $1-2.5 \%$ dengan komposisi utama yaitu senyawa seskuiterpenoid. Senyawa yang termasuk kedalam komponen seskuiterpenoid adalah curzerenone (zedoarin) yang merupakan komponen terbesar, furanodienone, furanodiene, curdione, curcumenol, isocurcumenol, zederone, curzeren, pyrocurcuzerenone, epicurcumenol, procurcumenol, dehydrocurdione, isofuranodienone, curcumeone dan curcumin ${ }^{[2,4]}$. Selain memiliki aktivitas antioksidan ${ }^{[8]}$, rimpang temu putih juga dapat menghambat pertumbuhan bakteri maupun jamur ${ }^{[9-11]}$.

Kandungan kimia yang terkandung dalam temulawak berupa fraksi pati, kurkuminoid dan minyak atsiri (3$12 \%)$. Yang termasuk kedalam kandungan fraksi pati meliputi abu, protein, lemak, karbohidrat, serat kasar, kurkuminoid, kalium, natrium, kalsium, magnesium, besi, mangan, dan kadmium. Sedangkan komponen khas minyak atsiri temulawak, diantaranya isofuranogermakren, trisiklin, allo-aromadendren, germakren dan xanthorrhizol ${ }^{[12]}$. Temulawak telah teruji memiliki aktivitas antibakteri terhadap Actinomyces viscous, Porphyromonas gingivalis, E. coli, Staphylococcus aureus, juga terhadap jamur Candida albican ${ }^{[13-15]}$.

Sebagaimana tanaman genus Curcuma lain, ketiga rimpang tanaman tersebut mengandung kurkuminoid dengan kadar yang berbeda-beda. . Gugus hidroksil fenolat yang terdapat dalam struktur kurkuminoid berperan dalam aktivitas antibakterinya ${ }^{[16]}$. Kurkumin juga berpotensi untuk digunakan dalam pengobatan gangguan kulit seperti acne, psoriasis, penuaan dini, 
juga perawatan luka yang Sebagian besar melibatkan infeksi bakteri ${ }^{[17]}$

Berdasarkan latar belakang tersebut, penelitian ini dilakukan untuk membandingkan dan menelaah kandungan senyawa, kadar kurkuminoid dan aktivitas antibakteri ekstrak rimpang Temu hitam (Curcuma aeruginosa Roxb.), Temu putih (Curcuma zedoaria (Christm.) Roscoe) dan Temulawak (Curcuma xanthorrhiza Roxb.) terhadap bakteri Staphylococcus aureus, Staphylococcus epidermidis, dan Propionibacterium acne.

\section{BAHAN DAN METODE}

\section{Bahan}

Bahan yang digunakan adalah rimpang Temu Hitam (Curcuma aeruginosa Roxb.), Temu Putih (Curcuma zedoaria (Christm.) Roscoe) dan Temulawak (Curcuma xanthorrhiza Roxb.) yang diperoleh dari Kebun Percobaan Manoko, Lembang, Kab. Bandung Barat. Bahan telah dideterminasi untuk diuji kebenaran spesiesnya di Herbarium Bandungensee, Sekolah Ilmu dan Teknologi Hayati, Institut Teknologi Bandung. Rimpang tanaman yang telah dicuci dan disortasi kemudian dikeringkan menggunakan oven pengering pada suhu $50^{\circ} \mathrm{C}$.

\section{Karakterisasi Simplisia}

Pemastian mutu simplisia dilakukan dengan uji karakterisasi simplisia dengan parameter uji kadar abu total, kadar sari larut air, kadar sari larut etanol dan susut pengeringan menurut prosedur dalam Farmakope Herbal Indonesia Edisi III ${ }^{[18]}$

\section{Ekstraksi}

Rimpang temulawak (Curcuma xanthorrhiza Roxb.), temu putih (Curcuma zedoaria Roxb.), dan temu hitam (Curcuma aeruginosa (Christm) Roscoe.), masingmasing 800 g simplisia di ekstraksi menggunakan metode maserasi dengan pelarut etanol 96\% sebanyak $4000 \mathrm{ml}$, dilakukan dengan penggantian pelarut sebanyak 3x24 jam. Setelah selesai kemudian ekstrak yang didapat dipekatkan menggunakan rotary evaporator untuk memperoleh ekstrak pekat ${ }^{[8]}$.

Ekstrak kemudian diuji keseragaman bobot jenis nya dengan menggunakan piknometer bersih, kering dan telah dikalibrasi. Bobot piknometer dan bobot air ditimbang pada suhu $25^{\circ} \mathrm{C}$. Ekstrak dibuat masingmasing dalam konsentrasi $1 \%$ dan dimasukan ke dalam piknometer kemudian ditimbang. Bobot ekstrak diperoleh dengan mengurangkan bobot piknometer kosong dari bobot piknometer yang telah diisi . Bobot Jenis dihitung dengan membandingkan bobot ekstrak dengan bobot standard (air) pada volume dan suhu pengukuran yang sama ${ }^{[19]}$.

\section{Penapisan Fitokimia}

Penapisan fitokimia merupakan tahap untuk mengetahui adanya kandungan metabolit sekunder dalam sampel uji yang sebagian besar merupakan 
reaksi pengujian warna dengan suatu pereaksi warna. Pengujian yang dilakukan pada ekstrak uji meliputi uji alkaloid, flavonoid, saponin, tannin, kuinon dan steroid/triterpenoid. Pengujian dilakukan dengan menggunakan metode Franswoth [20] yang dimodifikasi.

\section{Uji Alkaloid}

Sebanyak 2 g sampel dilembabkan dengan ammonia $25 \% \quad \mathrm{v} / \mathrm{v}$ dan ditambahkan $20 \mathrm{~mL}$ kloroform lalu digerus dan disaring. Campuran disaring dan filtrat berupa larutan organik digunakan untuk percobaan selanjutnya dan disebut larutan A. Larutan A diekstraksi dua kali dengan larutan asam klorida $10 \% \quad \mathrm{v} / \mathrm{v}$ ekstrak yang diperoleh disebut larutan B. Larutan A ini diteteskan pada kertas saring dan ditetesi pereaksi Dragendorff. Terbentuk warna merah atau jimgga pada kertas saring menunjukan adanya alkaloid. Ke dalam masing-masing $5 \mathrm{~mL}$ larutan B dalam tabung reaksi ditambahkan beberapa tetes pereaksi Dragendorff dan Mayer. Terbentuknya endapan putih dengan perekasi mayer menunjukan adanya alkaloid

\section{Uji Flavonoid}

Sebanyak $1 \mathrm{~g}$ sampel dalam $100 \mathrm{~mL}$ air panas didihkan selama 5 menit dan disaring sehingga diperoleh filtrat. Filtrat yang diperoleh digunakan untuk penapisan senyawa golongan saponin, kuinon dan tanin disebut larutan C. Sebanyak $5 \mathrm{~mL}$ filtrat dalam tabung reaksi ditambahkan serbuk magnesium dan $2 \mathrm{ml}$ asam klorida-etanol (1:1), kemudian dikocok dengan $10 \mathrm{~mL}$ amil alkohol. Rekasi positif ditunjukan dengan terbentuknya warna jingga, kuning atau merah pada lapisan amil alcohol.

3. Uji Saponin

Sebanyak $10 \mathrm{~mL}$ larutan $\mathrm{C}$ dalam tabung reaksi dikocok secara vertikal selama 10 detik, terbentuknya busa yang mantap selama tidak kurang dari 10 menit, setinggi satu sampai $10 \mathrm{~cm}$ yang tidal hilang ketika ditambahkan 1 tetes asam klorida $2 \mathrm{~N}$ menunjukan adanya saponin.

4. Uji Tanin

Sebanyak $5 \mathrm{ml}$ larutan $\mathrm{C}$ dalam tabung reaksi direaksikan dengan larutan besi (III) klorida. Jika terbentuk warna biru kehitaman menunjukan adanya senyawa fenol. Kemudian $5 \mathrm{~mL}$ larutan $\mathrm{C}$ ditambahkan larutan gelatin jika terbentuk endapan putih menunjukan adanya tannin.

\section{Uji Kuinon}

Sebanyak $5 \mathrm{~mL}$ larutan $\mathrm{C}$ ditambahkan beberpa tetes larutan natrium hidroksida, jika terbentuk warna merah menunjukan adanya kuinon. Dapat terjadi reaksi palsu dengan tannin. Pemeriksaan dilanjutkan dengan penambahan gelatin kemudian endapannya disaring dan filtratnya ditambahkan natrium hidroksida $1 \mathrm{~N}$. Bila tetap berwarna merah maka menunjukan adanya kuinon 
6. Uji Steroid/triterpenoid

Sebanyak $1 \mathrm{~g}$ sampel dimaserasi dengan $20 \mathrm{~mL}$ eter selama 2 jam, lalu disaring. Filtrat sebanyak $5 \mathrm{~mL}$ diuapkan dalam cawan penguap. Ke dalam residu ditambahkan perelsi Lieberman-Burchard (2 tets asam asetat anhidrat: 1 tetes asa sulfat pekat). Jika terbentuk warna hijau biru menunjukan adanya steroid.

\section{Penetapan Kadar Kurkuminoid}

Penetapan kadar kurkuminid pada ekstrak dilakukan menggunakan metode spektrofotometri UV-Vis, dengan standar Kurkuminoid. Sampel dan standar dilarutkan dalam metanol p.a. Larutan standar dibuat dalam konsentrasi. Kemudian dilakukan pengukuran absorbansi pada panjang gelombang maksimum 420 nm. Absorbansi sampel dibandingkan dengan kurkumin sebagai baku standar ${ }^{[21]}$

\section{Penentuan Konsentrasi Hambat Minimum (KHM) dan Konsentrasi Bunuh Minimum (KBM)}

Aktivitas antibakteri dilakukan terhadap tiga bakteri uji yaitu Staphylococcus aureus, Staphylococcus epidermidis dan Propionibacterium acne ditentukan melalui penentuan KHM dan KBM menggunakan metode mikrodilusi ${ }^{[22]}$.

Dimasukkan $100 \mu \mathrm{L}$ Muehler Hilton Broth (MHB) pada kolom pertama sebagai kontrol negatif media. Kemudian ditambahkan $5 \mu \mathrm{L}$ suspensi bakteri uji ke dalam $10 \mathrm{~mL}$ Muehler Hilton Broth (MHB), diaduk menggunakan alat vortex. Setelah itu dimasukan media yang telah dicampur dengan suspensi mikroba sebanyak $100 \mu \mathrm{L}$ pada kolom yang kosong (kolom ke2-12), dan ditambahkan $100 \mu \mathrm{L}$ larutan ekstrak yang telah diencerkan pada kolom ke-12, serta dihomogenkan. Kemudian diambil sebanyak 100 L kemudian dipindahkan ke kolom ke-11. Pengenceran terus dilakukan sampai pada kolom ketiga yang merupakan konsentrasi terkecil. Kolom ketiga akan memiliki konsentrasi ekstrak terendah. Setelah itu pelat diinkubasi pada suhu $37^{\circ} \mathrm{C}$ selama 24 jam. Kemudian diamati adanya bagian yang jernih (tidak ada pertumbuhan bakteri) tersebut dinyatakan sebagai KHM. Sebanyak 5 L alikuot dari setiap bagian yang jernih dipindahkan dalam nutrien agar dan diinkubasi pada suhu $37^{\circ} \mathrm{C}$ selama 24 jam kemudian diamati. Konsentrasi yang terendah tidak memperlihatkan pertumbuhan bakteri ditetapkan sebagai Konsentrasi Bunuh Minimum (KBM).

\section{HASIL DAN PEMBAHASAN}

Pemastian mutu simplisia yang digunakan dalam pengujian dengan parameter uji kadar abu total, kadar sari larut air, kadar sari larut etanol dan susut pengeringan menunjukkan simplisia memenuhi standar mutu ${ }^{[18]}$ sebagaimana yang ditampilkan dalam Tabel I. 
Tabel I. Hasil Karakterisasi Simplisia

\begin{tabular}{lccc}
\hline Parameter Uji & \multicolumn{3}{c}{ Hasil Pengamatan \% (b/b) } \\
\cline { 2 - 4 } & $\begin{array}{l}\text { Temu } \\
\text { Hitam }\end{array}$ & $\begin{array}{l}\text { Temu } \\
\text { Putih }\end{array}$ & Temulawak \\
\hline $\begin{array}{l}\text { Kadar Abu } \\
\text { Total }\end{array}$ & 7,5 & 3,5 & 5,5 \\
\hline $\begin{array}{l}\text { Kadar Sari } \\
\text { Larut Air }\end{array}$ & 24 & 25 & 19 \\
\hline $\begin{array}{l}\text { Kadar Sari } \\
\text { Larut Etanol }\end{array}$ & 11 & 14 & 18 \\
\hline $\begin{array}{l}\text { Susut } \\
\text { Pengeringan }\end{array}$ & 7.52 & 6.51 & 10.08 \\
\hline
\end{tabular}

Proses ekstraksi dilakukan menggunakan metode maserasi karena senyawa yang terkandung dalam ekstrak uji yaitu senyawa golongan kurkuminoid mempunyai sifat tidak stabil dalam pemanasan. Waktu kontak yang lebih lama antara pelarut dan simplisia memungkinkan proses penarikan senyawa aktif lebih optimal $^{[8,21]}$

Hasil pengujian bobot jenis (Tabel II) menunjukkan ketiga esktrak hasil pemekatan memiliki bobot jenis yang tidak berbeda secara signifikan. Hal ini menunjukkan bahwa tingkat kepekatan dan kemurnian ekstrak tidak berbeda secara signifikan.

Tabel II. Bobot Jenis Ekstrak

\begin{tabular}{lc}
\hline \multicolumn{1}{c}{ Ekstrak } & Bobot Jenis $(\mathbf{g} / \mathbf{m L})$ \\
\hline Temu Hitam & 0.813 \\
\hline Temu Putih & 0.811 \\
\hline Temulawak & 0.813
\end{tabular}

Hasil penapisan fitokimia menunjukkan ketiga ekstrak terdeteksi mengandung senyawa polifenol dan flavonoid. Kandungan senyawa kuinon hanya terdeteksi pada ekstrak temu hitam dan temu lawak. Senyawa saponin hanya terdeteksi pada ekstrak temu hitam dan temu putih. Sedangkan senyawa steroid/triterpenoid terdeteksi pada ekstrak temu putih dan temulawak. Senyawa alkaloid dan tannin tidak terdeteksi pada ketiga ekstrak uji.

Kandungan senyawa flavonoid pada ketiga sampel uji ini akan berperan dalam aktivitas antibakterinya. Mekanisme senyawa flavonoid yang diduga dapat menghambat pertumbuhan antibakteri adalah dengan cara merusak dinding sel sehingga menyebabkan kematian sel. Selain itu flavonoid juga dapat menghambat pertumbuhan protein yang mengakibatkan terhambatnya pertumbuhan mikroba ${ }^{[23]}$. Kandungan senyawa kuinon pada temu putih dan temulawak dapat berperan sebagai antibakteri dengan cara membentuk senyawa kompleks yang bersifat irreversible dengan residu asam amino nukleofilik pada protein transmembran pada membrane plasma, polipeptida dinding sel dan enzim-enzim yang terdapat pada permukaan membrane sel bakteri sehingga mengganggu kehidupan sel bakteri. Sedangkan kandungan senyawa steroid/triterpenoid pada ekstrak temu putih dan temulawak berpeluang sebagai antibakteri dengan mekanisme kerja bereaksi dengan protein transmembran pada membran luar dinding sel bakteri, yang akan membentuk ikatan polimer kuat dan mengakibatkan rusaknya porin. Porin merupakan pintu keluar masuknya senyawa sehingga ketika porin rusak akan mengakibatkan berkurangnya permeabilitas dinding sel bakteri. Selain itu dinding sel bakteri juga 
akan mengalami kekurangan nutrisi yang akan menghambat pertumbuhan bakteri atau mati ${ }^{[24]}$.

Selain kandungan metabolit sekunder fenolat, flavonoid, kuinon dan steroid/triterpenoid, kandungan senyawa kurkuminoid sebagai senyawa penanda genus Curcuma juga berperan sebagai antibakteri ${ }^{[25-27]}$.

Hasil penetapan kadar kurkuminoid pada ketiga ekstrak uji pada tabel III membuktikan bahwa senyawa kurkuminoid paling tinggi terkandung dalam ekstrak temulawak.

Tabel III. Kandungan Kurkuminoid pada Ekstrak

\begin{tabular}{lc}
\hline \multicolumn{1}{c}{ Ekstrak } & $\begin{array}{c}\text { Kadar Kurkuminoid } \\
\text { (mg CE/g ekstrak) }\end{array}$ \\
\hline Temu Hitam & $0.84 \pm 0.006$ \\
\hline Temu Putih & $2.33 \pm 0.006$ \\
\hline Temulawak & $16.07 \pm 0.023$ \\
\hline
\end{tabular}

Dengan kandungan senyawa kurkuminoid yang lebih tinggi, aktivitas antibakteri ekstrak temulawak juga memiliki nilai KHM paling rendah untuk ketiga bakteri uji dibandingkan dengan kedua ekstrak lainnya sebagaimana yang diperlihatkan pada nilai KHM ekstrak uji pada tabel IV.

Tabel IV. Hasil Penentuan Nilai KHM

\begin{tabular}{cccc}
\hline Ekstrak & \multicolumn{3}{c}{ KHM $(\mu \mathrm{g} / \mathrm{mL})$} \\
\cline { 2 - 4 } & S. aureus & S. epidermidis & P. acne \\
\hline $\begin{array}{c}\text { Temu } \\
\text { Hitam }\end{array}$ & 256 & $>512$ & $>512$ \\
\hline Temu Putih & 512 & $>512$ & $>512$ \\
\hline Temulawak & 64 & 256 & 32 \\
\hline
\end{tabular}

Menurut Holetz. et al (2002) jika ekstrak menghasilkan nilai KHM kurang dari $100 \mu g / m L$, aktivitas antibakteri dikatakan kuat, $100-500 \mu g / m L$ tergolong sedang, jika KHM menghasilkan nilai 500-1000 $\mu \mathrm{g} / \mathrm{mL}$ maka aktivitas antibakteri dianggap lemah dan jika KHM yang diperoleh lebih dari $1000 \mu \mathrm{g} / \mathrm{mL}$ maka sediaan uji dianggap tidak aktif ${ }^{[28]}$.

Dari data yang telah diperoleh dapat dikatakan bahwa ekstrak temu putih dan temu hitam memiliki aktivitas yang lemah sebagai antibakteri terhadap bakteri Staphylococcus epidermidis dan Propionibacterium acne karena KHM yang didapat lebih dari 512 atau berada pada rentang $1000 \mu \mathrm{g} / \mathrm{mL}$. Sedangkan Ekstrak temulawak menunjukkan aktivitas yang kuat terhadap bakteri Staphylococcus aereus dan Propionibacterium acne serta aktivitas sedang terhadap Staphylococcus epidermidis.

Hasil uji KBM terhadap bakteri Staphylococcus aureus, Staphylococcus epidermidis dan Propionibacterium acne berada pada konsentrasi $>512$ $\mu g / m L$. Sehingga dapat disimpulkan bahwa ekstrak temulawak, temu putih dan temu hitam bersifat bakteriostatik terhadap bakteri uji pada konsentrasi KHM nya.

Bakteri uji yang digunakan termasuk golongan bakteri gram positif. Bakteri gram positif memiliki dinding sel luar yang tebal dibandingkan dengan bakteri gram negatif, terbuat dari polimer kompleks yang berikatan silang disebut dengan peptidoglikan. Peptidoglikan tidak mudah ditembus oleh antibiotik karena 
lapisannya yang tebal, sehingga membutuhkan antibiotik atau metabolit sekunder yang kuat untuk dapat menembus lapisan peptidoglikan tersebut ${ }^{[29]}$.

\section{SIMPULAN DAN SARAN}

Rimpang Temu hitam (Curcuma aeruginosa Roxb.), Temu putih (Curcuma zedoaria (Christm.) Roscoe) dan Temulawak (Curcuma xanthorrhiza Roxb.) mengandung senyawa polifenol dan flavonoid. Sedangkan kuinon hanya ditemukan pada temu hitam dan temu lawak serta saponin pada ekstrak temu hitam dan temu putih. Senyawa steroid/triterpenoid hanya terdeteksi pada ekstrak temu putih dan temulawak.

Dari ketiga rimpang tersebut, temulawak memiliki kandungan kurkuminoid paling tinggi dan memiliki aktivitas antibakteri terhadap bakteri Staphylococcus aureus, Staphylococcus epidermidis dan Propionibacterium acne paling kuat dibanding dua rimpang lainnya.

\section{UCAPAN TERIMAKASIH}

Tim Peneliti mengucapkan Terima kasih kepada LPPM Universitas Bhakti Kencana yang telah mendanai penelitian ini.

\section{DAFTAR PUSTAKA}

1. Subositi D, Wahyono S. Study of the genus curcuma in Indonesia used as traditional herbal medicines. Biodiversitas 2019;20(5):1356-61.

2. Dalimarta S. Atlas Tumbuhan Obat Indonesia Jilid 3. Jakarta: Trubus Agriwidya; 2003.
3. Evizal R. Tanaman Rempah dan Fitofarmaka. Lampung: Lembaga Penelitian Universitas Lampung; 2013.

4. Dosoky NS, Setzer WN. Chemical composition and biological activities of essential oils of curcuma species. Nutrients 2018;10(9):10-7.

5. Suphrom N, Pumthong G, Khorana N, Waranuch N, Limpeanchob N, Ingkaninan K. Anti-androgenic effect of sesquiterpenes isolated from the rhizomes of Curcuma aeruginosa Roxb. Fitoterapia 2012;83(5):86471 .

6. Choudhury D, Ghosal M, Das AP, Mandal P. Development of single node cutting propagation techniques and evaluation of antioxidant activity of Curcuma aeruginosa Roxburgh rhizome. Int J Pharm Pharm Sci 2013;5(2):227-34.

7. Nugrahaningtyas KDWI, Matsjeh S, Wahyuni TDWI. Isolasi dan Identifikasi Senyawa Flavonoid dalam Rimpang Temu Ireng (Curcuma aeruginosa Roxb.). Biofarmasi 2005;3(1):32-8.

8. Marliani L, Budiana W, Anandari Y. The Effect of Extraction Condition on The Polyphenol Content and Antioxidant Activity of Curcuma zedoaria (Christm.) Roscoe Rhizome. Indones J Pharm Sci Technol 2017;4(2):57.

9. Nuryanti S. Aktivitas Antifungi Temu Putih (Curcuma zedoaria) terhadap Trichophyton mentagrophytes. As-syifaa 2016;08(02):50-7.

10. Sarjono P. Aktivitas Antibakteri Rimpang Temu Putih (Curcuma Mangga Vall). J Sains Dan Mat 2007;15(2):89-93.

11. Das K, Rahman MA. Analgesic and antimicrobial activities of Curcuma zedoaria. Int J Pharm Pharm Sci 2012;4(SUPPL. 5):322_8.

12. Dalimarta S. Atlas Tumbuhan Obat Indonesia Jilid 2. Jakarta: Trubus Agriwidya; 2000.

13. Hwang JK, Shim JS, Pyun YR. Antibacterial activity of xanthorrhizol from Curcuma xanthorrhiza against oral pathogens. Fitoterapia 2000;71(3):321-3.

14. Purnamaningsih N, Kalor H, Atun S. Uji Aktivitas Antibakteri Ekstrak Temulawak (Curcuma Xanthorrhiza) Terhadap Bakteri Escherichia coli ATCC 11229 dan Staphylococcus aureus ATCC 25923. J Penelit Saintek 2017;22(2):140-7. 
15. Dewi Novianti. Kemampuan Antifungi Ekstrak Rimpang Temulawak (Curcuma xanthorrhiza) Terhadap Candida albicans. J Ilm Mat dan Ilmu Pengetah Alam 2016;13(2):69-79.

16. Sidik, Mulyono MW. MA. Temulawak (Curcuma xanthorriza Roxb.). Jakarta: Yayasan Pengembangan Obat Bahan Alam Phytomedica.; 1992.

17. Vollono L, Falconi M, Gaziano R, Lacovelli F, Dika E, Terracciano C, et al. Potential of Curcumin in Skin Disorders. Nutrients 2019;11(9).

18. Kemenkes RI DK dan A. Farmakope Herbal Indonesia. 2nd ed. Jakarta: Kementrian Kesehatan RI; 2017.

19. Depkes RI. Farmakope Indonesia. IV. Jakarta: Departemen Kesehatan Republik Indonesia; 1995.

20. Farnsworth N. Biological and phytochemical screening of plants. J Pharm Sci 1966;151(3712):874-5.

21. Marliani L, Anandari Y, Budiana W. Pengaruh Pelarut, Waktu Dan Suhu Ekstraksi Terhadap Kandungan Senyawa Flavonoid Dan Kurkuminoid Ekstrak Rimpang Temu Putih (Curcuma zedoaria (Christm.)Roscoe). J Farm Galen 2017;4(Edisi Khusus SemNas TOI4):35-9.

22. CLSI. Methods for Dilution Antimicrobial Susceptibility Tests for Bacteria That Grow Aerobically ; Approved Standard - Ninth Edition. Clinical and Laboratory Standards Institute; 2012.

23. Heinrich M. Farmakognosi dan Fitoterapi. Jakarta: EGC; 2009.

24. Cowan MM. Plant Products as Antimicrobial Agents. Clin Microbiol Rev 1999;12:564-82.

25. Teow SY, Liew K, Ali SA, Khoo ASB, Peh SC. Antibacterial Action of Curcumin against Staphylococcus aureus: A Brief Review. J Trop Med 2016;2016.

26. Zorofchian Moghadamtousi S, Abdul Kadir H, Hassandarvish P, Tajik H, Abubakar S, Zandi $\mathrm{K}$. A review on antibacterial, antiviral, and antifungal activity of curcumin. Biomed Res Int 2014;2014.

27. Gunes H, Gulen D, Mutlu R, Gumus A, Tas T, Topkaya AE. Antibacterial effects of curcumin: An in vitro minimum inhibitory concentration study. Toxicol Ind Health 2016;32(2):246-50.
28. Holetz FB, Pessini GL, Sanches NR, Cortez AG, Nakamura CV, Prado B, et al. Screening of Some Plants Used in the Brazilian Folk Medicine for the Treatment of Infectious Diseases. Mem Inst Oswaldo Cruz 2002;97(7):1027-31.

29. Pratiwi, Sylvia T. Mikrobiologi Farmasi. Jakarta: Penerbit Erlangga; 2008. 